\title{
QUALITY CHARACTERISTICS OF THE MIXTURES OF SOME WARM SEASON PERENNIAL GRASSES WITH ALFALFA (MEDICAGO SATIVA L.) UNDER IRRIGATED CONDITIONS IN THE MEDITERRANEAN REGION OF TURKEY
}

\author{
CinAR, S. ${ }^{12^{*}}-$ HATIPOGLU, R. ${ }^{3}-$ AvCI, M. ${ }^{4}-$ Gundel, F. D. ${ }^{5}-$ AKTAS, A. ${ }^{5}$ \\ ${ }^{I}$ Department of Horticulture and Field Crops, Faculty of Agriculture, Kyrgyz-Turkish Manas \\ University, Bishkek, Kyrgyzstan \\ ${ }^{2}$ Department of Plant and Animal Production, Technical Vocational School, Kilis 7 Aralik \\ University, Kilis, Turkey \\ ${ }^{3}$ Department of Field Crops, Faculty of Agriculture, Cukurova University, Adana, Turkey \\ ${ }^{4}$ Faculty of Plant Production and Technology, Nigde Omer Halisdemir University \\ Nigde, Turkey \\ ${ }^{5}$ East Mediterranean Agricultural Research Institue, Adana, Turkey \\ *Corresponding author \\ e-mail:scinar01@hotmail.com \\ (Received $3^{\text {rd }}$ Aug 2018; accepted $8^{\text {th }}$ Oct 2018)
}

\begin{abstract}
This study was conducted to determine forage quality characteristics of duo (alfalfa + one grass) and trio (alfalfa + two grasses) mixtures of some warm season perennial grass species such as dallis grass (Paspalum dilatatum Poir.), Rhodes grass (Chloris gayana L.), Bermuda grass (Cynodon dactylon (L.) Pers.) Guineae grass (Panicum maximum Jacq.), blue couch grass (Digitaria didactyla Willd) and finger grass (Digitaria milanjiana (Rendle) Stapf) with alfalfa as well as their pure sowings under irrigated conditions in the Mediterranean region of Turkey during 2010-2012 growing seasons. In the study, crude protein contents, crude protein yields, acid detergent fiber contents (ADF), neutral detergent fiber contents (NDF), digestible dry matter contents (DDM) and relative feed values (RFV) of the mixtures and pure sowings were determined. The experimental design was completely randomized block design with three replications. The results of the study showed that there were significant differences among mixtures and pure sowings in the forage quality characteristics. The highest crude protein yield (3948.5) $\mathrm{kg} \mathrm{ha}^{-1}$ ) was obtained from the mixture of dallis grass + alfalfa. The highest crude protein ratio $(20.5 \%)$, DDM ratio $(68.3 \%)$ and RFV (170.88) was obtained from the pure alfalfa. The highest ADF (40.2\%) and NDF (70.9\%) was obtained from the pure Guinea grass. From the results of the study, it was concluded that Bermuda grass, Rhodes grass, blue couch grass and dallis grass could be used to establish of duo and trio pasture mixtures with alfalfa, having long grazing season and giving high hay quality. Before the establishment of such pasture mixtures, it is needed to search for proper mixture ratios and proper management techniques of the mixtures.
\end{abstract}

Keywords: warm season perennial grasses, alfalfa, mixture, forage quality, $A D F, N D F, R F V$

\section{Introduction}

Quality forage for livestock is produced from natural pastures and forage crops grown under field conditions worldwide. Legume-grass mixtures are easily established in degenerated pasture or field conditions. Legumes are rich in terms of protein contents, whereas grasses have higher carbohydrate contents and can benefit from the nitrogen fixed by legumes when they are grown together. Thus, legume-grass mixtures 
may be more productive than monoculture grasses. Alfalfa (Medicago sativa L.) is grown under both irrigated and dry conditions and it may be more productive in mixtures with grasses. Several studies reported that alfalfa-grass mixtures resulted in higher yields and higher nutritional quality as compared with grasses alone (Albayrak and Turk, 2011).

The advantages of cool season legumes in cool season pastures and hay lands have been well documented, but there is little information on mixing legumes with warm season grasses. Some researchers reported that growing warm-season grasses with legumes resulted in higher dry matter yields than pure sowings (Aganoglu, 1985; Blanchet et al., 1995; Larbi et al., 1995; Gettle et al., 1996; Tessema and Baars, 2006; Cinar and Hatipoglu, 2014).

Mediterranean region of the Turkey experiences long periods of drought, especially in mid-summer. High temperatures and low precipitation are detrimental to production of cool season forages. Lack of productivity of cool season pastures during the summer months often results in overgrazing. Perennial warm season grasses produce their yields in midsummer, which could provide forage production during that period (Jung et al., 1978).

Methods to effectively establish and manage some warm season grasses for yield have been characterized for Mediterranean conditions (Cinar and Hatipoglu, 2014). Using the potential of these species to provide a dependable pasture forage supply during summer months warrants investigation of options to enhance their quality.

Rhodes grass is one of the main sub-tropical grasses and is widely grown in Africa, Australia, Japan and South America as well as in the Middle East under irrigation for both forage and soil conservation purposes. Dallis grass is a summer-active perennial grass native to the humid sub-tropics of southern Brazil, Argentina and Uruguay. It is now widespread in many areas of the world, and is capable of very high production under suitable conditions. Bermuda grass has been widely used in tropical and warm temperate regions as a pasture grass and is one of the major turf grasses in the world. Blue couch grass is similar to Bermuda grass. It differs from Bermuda grass in its shorter, broader leaf and its distinctive bluish colour (Skerman and Riveros, 1990).

Guinea grass is widely distributed in the tropical and sub-tropical areas of the world. It can produce over 20 tons $\mathrm{dm} \mathrm{ha}^{-1}$ but suffers from drought when dry matter production can be reduced to as low as $40 \%$ of its yield potential. Guinea grass responds well to cutting and grazing, and is fairly pest resistant (Nung and Binh, 2014).

Finger grass is a native of tropical Eastern and Southern Africa, from Ethiopia down to South Africa. It is found in semiarid to wet equatorial areas, with average annual rainfall between 450 to $1700 \mathrm{~mm}$. It grows in grasslands on sandy loam soils and in open woodlands on heavy black or sandy soils. An annual dry matter yield of up to 15 $\mathrm{t} / \mathrm{ha}$ has been achieved from well fertilized finger grass. It is very palatable to all types of stock as green feed, dry feed or as hay. It can be used in mixed pastures or as a hay crop. It should not be grazed in the wet season of establishment (Cameron et al., 2010).

This study was conducted to determine forage quality of duo (one grass + alfalfa) and trio (two grass + alfalfa) mixtures of some perennial warm season grass species such as dallis grass (Paspalum dilatatum Poir.), Rhodes grass (Chloris gayana L.), Bermuda grass (Cynodon dactylon (L.) Pers.) Guineae grass (Panicum maximum Jacq.), blue couch grass (Digitaria didactyla Willd) and finger grass (Digitaria milanjiana (Rendle) Stapf) with alfalfa (Medicago sativa L.) as well as their pure sowings under irrigated conditions in the Mediterranean region of Turkey. 
This paper was prepaired from a part of data obtained from the research conducted to determine the forage yields and qualities of duo (one grass + alfalfa) and trio (two grass + alfalfa) mixtures of some perennial warm season grass species such as dallis grass (Paspalum dilatatum Poir.), Rhodes grass (Chloris gayana L.), Bermuda grass (Cynodon dactylon (L.) Pers.), Guineae grass (Panicum maximum Jacq.), blue couch grass (Digitaria didactyla Willd) and finger grass (Digitaria milanjiana (Rendle) Stapf) with alfalfa (Medicago sativa L.) as well as their pure growings under irrigated conditions in Mediterranean region of Turkey. A paper from data related to the yields and some other characteristics of the mentioned mixtures as well as pure growings had been published (Cinar et al., 2014).

\section{Materials and methods}

\section{Materials}

The study was carried out during 2011 and 2012 years in Adana province ( $36^{\circ} 51^{\prime} \mathrm{N}$, $35^{\circ} 20^{\prime} \mathrm{E}$, elevation $12 \mathrm{~m}$ ), located in the Mediterranean region of Turkey (Fig. 1).

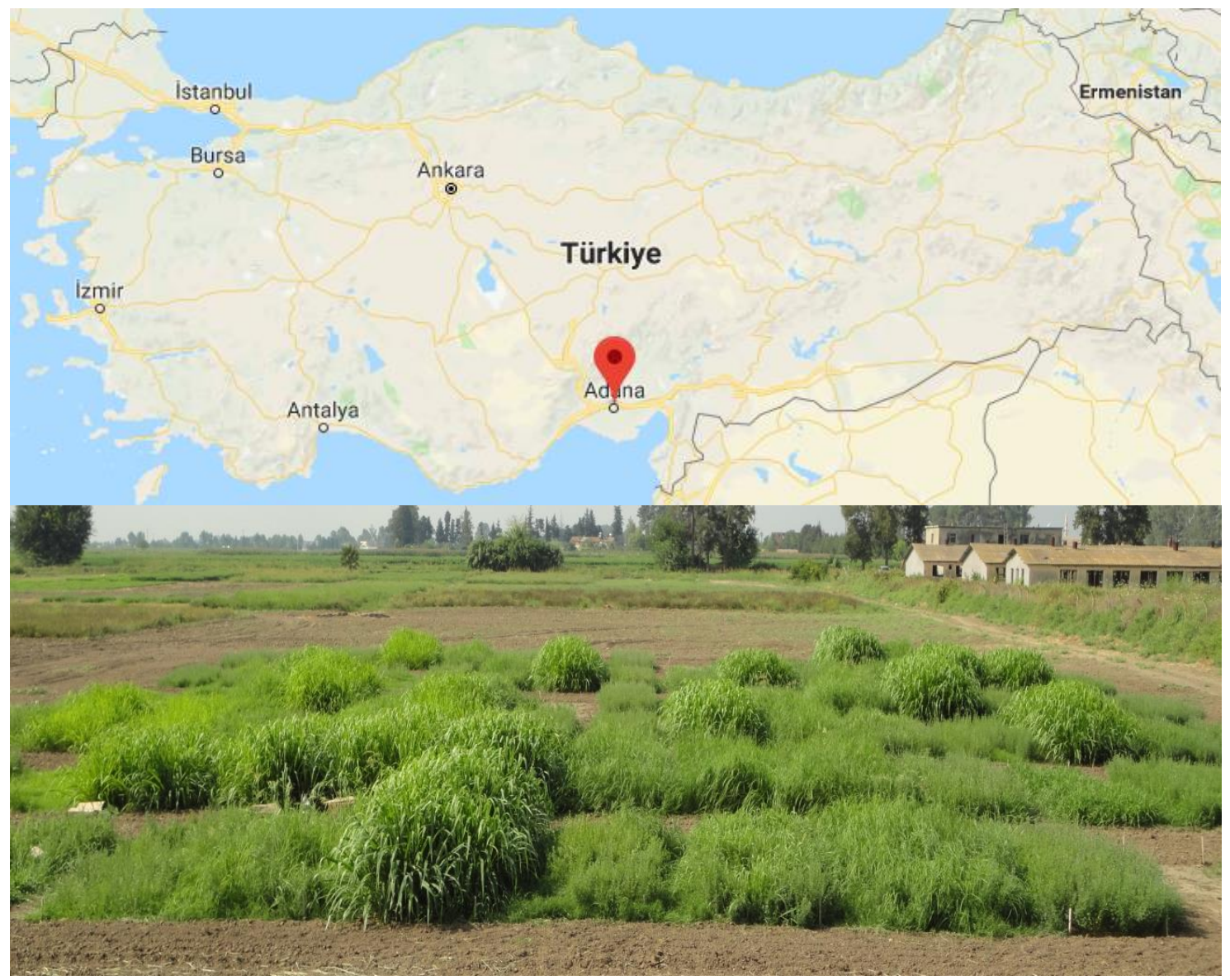

Figure 1. The map of Turkey and picture of study area

The experimental area has typically Mediterranean climate with hot and dry summer and heavy precipitation during winter. According to the average of long years, the coolest month is January with a monthly mean temperature of $9.9{ }^{\circ} \mathrm{C}$ and the hottest 
month is July with $29.7^{\circ} \mathrm{C}$. The total precipitation was higher in $2011(687.7 \mathrm{~mm})$ and in $2012(1048.8 \mathrm{~mm})$ compared with the longterm precipitation mean $(647.1 \mathrm{~mm})$. The means of the temperature and relative humidity during the experimental period were close to the long-term means (Anonymous, 2013).

The research area has a flat land; its soil texture is classified as silty clay with slightly alkaline, which contained medium organic matter, poor phosphorus $(\mathrm{P})$, zinc ( $\mathrm{Zn})$ and calcium (Ca) contents (Anonymous, 2011).

Dallis grass (Paspalum dilatatum Poir.), Rhodes grass (Chloris gayana L.), Bermuda grass (Cynodon dactylon (L.) Pers.) Guineae grass (Panicum maximum Jacq.), blue couch grass (Digitaria didactyla Willd), finger grass (Digitaria milanjiana (Rendle) Stapf) and alfalfa (Medicago sativa L.) were used as experimental material. In the research, duo and trio mixtures of the mentioned grass species with alfalfa as well as their pure sowings were studied.

\section{Methods}

The experiment was established according to the randomized complete block design with three replications. There were 28 treatment plots in each block. Each plot consisted of 6 rows each $5 \mathrm{~m}$ in length. The row spacing was $25 \mathrm{~cm}$. The seeding rates for dallis grass, Rhodes grass, Bermuda grass, Guineae grass, finger grass, blue couch grass and alfalfa in pure sowing were $11 \mathrm{~kg} \mathrm{ha}^{-1}, 4 \mathrm{~kg} \mathrm{ha}^{-1}, 10 \mathrm{~kg} \mathrm{ha}^{-1}, 6 \mathrm{~kg} \mathrm{ha}^{-1}, 8 \mathrm{~kg} \mathrm{ha}^{-1}, 8 \mathrm{~kg} \mathrm{ha}^{-}$ ${ }^{1}$ and $10 \mathrm{~kg} \mathrm{ha}^{-1}$, respectively. Seed mixtures consisted of $30 \%$ alfalfa and $70 \%$ grasses. Seed ratio of each grass species in trio mixtures was 35\%. The seeds of alfalfa and grass species were sown in the same rows. Sowing was done by hand on May 28th 2011. Plots were fertilized with $100 \mathrm{~kg} \mathrm{ha}^{-1} \mathrm{~N}$ and $100 \mathrm{~kg} \mathrm{ha}^{-1} \mathrm{P}$ at sowing (Avci, 2000). The plots were irrigated once after each harvest. The harvest time was based on the $10 \%$ flowering stage of alfalfa (Cinar et al., 2014). The plots were harvested at $5 \mathrm{~cm}$ cutting height. The plots were harvested 3 and 5 times during the growing season of 2011 and 2012, respectively.

All samples were dried at $70{ }^{\circ} \mathrm{C}$ for $48 \mathrm{~h}$ and weighed. The samples from the mixture plots were hand-separated to the mixture components before the drying. Dry matter content was determined from ground samples dried at $105^{\circ} \mathrm{C}$ for $24 \mathrm{~h}$ (Sleugh et al., 2000).

Contents of crude protein, acid detergent fiber (ADF) and neutral detergent fiber (NDF) of samples were determined using Infrared Reflectance Spectroscopy (NIRS) (Hoy et al., 2002; Aydin et al., 2010). NIRS was calibrated using software program coded IC-0904 FE hay and fresh forage.

Crude protein yield (CPY), digestible dry matter yield (DDMY), dry matter intake (DMI), digestible dry matter (DDM) and relative feed value (RFV) were estimated according to the following equations adapted from Sheaffer et al. (1995) (Eqs. 1-4):

$$
\begin{gathered}
\mathrm{DMI}=120 /(\mathrm{NDF} \%) \text { dry matter basis } \\
\mathrm{DDM}=88.9-(0.779 \times \mathrm{ADF} \% \text { dry matter basis }) \\
\mathrm{RFV}=(\mathrm{DDM} \% \times \mathrm{DMI}) / 1.29 \\
\mathrm{CPY}=\text { Crude protein content }(\mathrm{CP} \%) \times \text { dry matter yield }(\mathrm{DMY})
\end{gathered}
$$


Relative feed value (RFV) was calculated by multiplying digestible dry matter by dry matter intake and then dividing by 1.29 (Schroeder, 1994).

\section{Statistical analyses}

The experimental design was completely randomized block design with three replications. Data were analyzed by using MSTATC software program (V.1.2, Michigan State University, USA). The differences between means were separated by Duncan multiple range test $(\mathrm{P} \leq 0.05)$ (Steel and Torrie, 1960).

\section{Results}

\section{Crude protein ratio and crude protein yield}

The results of the variance analysis showed that the crude protein ratio was influenced by pure sowings and mixtures as well as years. Year $\mathrm{x}$ treatment (pure sowings and mixtures) interaction was also statistically significant. Average crude protein ratios in the second year were significantly higher than that in the first year (Table 1). The alfalfa sown in April, normally sown in November under Mediterranean conditions, produced lower hay yield than that sown in November in the first year. Therefore contribution of the alfalfa on the yield of the mixtures was significantly lower than those in the second year. Lower alfalfa ratio in the hay yields of mixtures in the first year resulted in the lower averaged crude protein ratio than those in the second year.

In the first year, crude protein content of alfalfa dry matter was statistically significant higher than those of the other pure sowings and all of the mixtures (Table 1). The mixtures GG+A gave significantly lower crude protein ratio than pure sowings and other mixtures.

In the second year, the mixture of $\mathrm{RG}+\mathrm{FG}+\mathrm{A}$ produced dry matter with statistically significant higher crude protein content than the all of the pure sowings with the exception alfalfa and all of the other mixtures with the exceptions of $\mathrm{RG}+\mathrm{GG}+\mathrm{A}$, $\mathrm{GG}+\mathrm{A}, \mathrm{A}, \mathrm{FG}+\mathrm{A}, \mathrm{BG}+\mathrm{A}, \mathrm{DG}+\mathrm{A}, \mathrm{RG}+\mathrm{A}, \mathrm{GG}+\mathrm{FG}+\mathrm{A}, \mathrm{GG}+\mathrm{BCG}+\mathrm{A}$ and $\mathrm{RG}+\mathrm{BCG}+\mathrm{A}$. On the other hand, pure sowing of Guinea grass gave significantly lower crude protein content than the pure sowing of Rhodes grass and all of the mixtures. All of the pure sowings of the grasses gave the dry matter with statistically significant lower crude protein content than the pure sowing of alfalfa and all of the mixtures.

According to the averaged values over two years, the highest crude protein ratio was obtained from pure sown alfalfa. Pure sowings of Guinea grass produced the dry matter with significantly lower crude protein content than the other pure sowings and mixtures.

The results of the variance analysis showed that the crude protein yield was influenced by pure sowings and mixtures as well as years. Year x treatment interaction was also statistically significant. The averaged crude protein yield in first year was significantly lower than those in the second year (Table 2). The variation in the crude protein yield of the pure sowings and mixtures depending on the years was due to the variation in dry matter yield and crude protein ratio (Cinar et al., 2014; Table 1).

In the first year of the experiment, the mixture of RG+A gave statistically significant higher crude protein yield than the pure growings of Bermuda grass and blue couch grass and the mixtures of $\mathrm{GG}+\mathrm{A}, \mathrm{BCG}+\mathrm{A}, \mathrm{GG}+\mathrm{BCG}+\mathrm{A}$ and $\mathrm{GG}+\mathrm{FG}+\mathrm{A}$. In the second year, the mixture of alfalfa + dallis grass gave significantly higher crude protein yield 
than the pure sowings and the other mixtures with the exception of the alfalfa + Bermuda grass mixture.

Table 1. Crude protein ratios (\%) of dry matters from pure sowings and alfalfa-grass mixtures

\begin{tabular}{|c|c|c|c|}
\hline \multirow{2}{*}{ Mixture or pure sowing } & \multicolumn{2}{|c|}{ Years } & \multirow{2}{*}{ Average } \\
\hline & 2011 & 2012 & \\
\hline Bermuda grass (BG) & $10.6 \mathrm{fg} *$ & 9.91 & $10.3 \mathrm{~m}$ \\
\hline Dallis grass (DG) & $12.8 \mathrm{e}$ & 10.11 & $11.4 \mathrm{kl}$ \\
\hline Rhodes grass (RG) & $9.6 \mathrm{gh}$ & $12.4 \mathrm{~h}$ & $11.0 \mathrm{~lm}$ \\
\hline Guinea grass (GG) & $8.1 \mathrm{hl}$ & 9.51 & $8.8 \mathrm{n}$ \\
\hline Blue couch grass (BCG) & $11.0 \mathrm{e}-\mathrm{g}$ & 10.41 & $10.7 \mathrm{~lm}$ \\
\hline Finger grass (FG) & $9.8 \mathrm{gh}$ & 10.31 & $10.1 \mathrm{~m}$ \\
\hline Alfalfa (A) & $20.4 \mathrm{a}$ & 20.7 a-d & $20.5 \mathrm{a}$ \\
\hline $\mathrm{BG}+\mathrm{A}$ & $16.6 \mathrm{bc}$ & $20.0 \mathrm{a}-\mathrm{e}$ & $18.3 \mathrm{~b}$ \\
\hline $\mathrm{DG}+\mathrm{A}$ & $15.8 \mathrm{~b}-\mathrm{d}$ & $20.4 \mathrm{a}-\mathrm{d}$ & $18.1 \mathrm{bc}$ \\
\hline $\mathrm{RG}+\mathrm{A}$ & $11.1 \mathrm{e}-\mathrm{g}$ & $20.1 \mathrm{a}-\mathrm{e}$ & $15.6 \mathrm{fg}$ \\
\hline $\mathrm{GG}+\mathrm{A}$ & 7.01 & $20.8 \mathrm{a}-\mathrm{c}$ & $13.9 \mathrm{~h} 1$ \\
\hline $\mathrm{BCG}+\mathrm{A}$ & $17.1 \mathrm{~b}$ & $19.0 \mathrm{ef}$ & $18.0 \mathrm{bc}$ \\
\hline $\mathrm{FG}+\mathrm{A}$ & $16.5 \mathrm{~b}-\mathrm{d}$ & $20.4 \mathrm{a}-\mathrm{d}$ & $18.4 \mathrm{~b}$ \\
\hline $\mathrm{BG}+\mathrm{DG}+\mathrm{A}$ & $17.0 \mathrm{~b}$ & $19.6 \mathrm{c}-\mathrm{f}$ & $18.3 \mathrm{~b}$ \\
\hline $\mathrm{BG}+\mathrm{RG}+\mathrm{A}$ & $12.0 \mathrm{ef}$ & $19.4 \mathrm{~d}-\mathrm{f}$ & $15.7 \mathrm{fg}$ \\
\hline $\mathrm{BG}+\mathrm{GG}+\mathrm{A}$ & $8.7 \mathrm{~h} 1$ & $15.9 \mathrm{~g}$ & $12.3 \mathrm{jk}$ \\
\hline $\mathrm{BG}+\mathrm{BCG}+\mathrm{A}$ & $15.1 \mathrm{~cd}$ & $18.9 \mathrm{ef}$ & $17.0 \mathrm{c}-\mathrm{e}$ \\
\hline $\mathrm{BG}+\mathrm{FG}+\mathrm{A}$ & $14.7 \mathrm{~d}$ & $19.5 \mathrm{c}-\mathrm{f}$ & $17.1 \mathrm{c}-\mathrm{e}$ \\
\hline $\mathrm{DG}+\mathrm{RG}+\mathrm{A}$ & $10.6 \mathrm{fg}$ & $18.9 \mathrm{ef}$ & $14.8 \mathrm{gh}$ \\
\hline $\mathrm{DG}+\mathrm{GG}+\mathrm{A}$ & $8.1 \mathrm{~h} 1$ & $18.5 \mathrm{f}$ & $13.3 \mathrm{ij}$ \\
\hline $\mathrm{DG}+\mathrm{BCG}+\mathrm{A}$ & $16.9 \mathrm{bc}$ & $19.4 \mathrm{~d}-\mathrm{f}$ & $18.1 \mathrm{bc}$ \\
\hline $\mathrm{DG}+\mathrm{FG}+\mathrm{A}$ & $16.0 \mathrm{~b}-\mathrm{d}$ & $19.0 \mathrm{ef}$ & $17.5 \mathrm{~b}-\mathrm{d}$ \\
\hline $\mathrm{RG}+\mathrm{GG}+\mathrm{A}$ & $8.3 \mathrm{~h} 1$ & $21.1 \mathrm{ab}$ & $14.7 \mathrm{gh}$ \\
\hline $\mathrm{RG}+\mathrm{BCG}+\mathrm{A}$ & $12.7 \mathrm{e}$ & 19.9 a-e & $16.3 \mathrm{ef}$ \\
\hline $\mathrm{RG}+\mathrm{FG}+\mathrm{A}$ & 11.8 ef & $21.2 \mathrm{a}$ & $16.5 \mathrm{~d}-\mathrm{f}$ \\
\hline $\mathrm{GG}+\mathrm{BCG}+\mathrm{A}$ & $8.7 \mathrm{~h} 1$ & 19.9 a-e & $14.3 \mathrm{~h} 1$ \\
\hline $\mathrm{GG}+\mathrm{FG}+\mathrm{A}$ & $8.3 \mathrm{~h} 1$ & $21.1 \mathrm{ab}$ & $14.7 \mathrm{gh}$ \\
\hline $\mathrm{FG}+\mathrm{BCG}+\mathrm{A}$ & $15.2 \mathrm{~b}-\mathrm{d}$ & $19.8 \mathrm{~b}-\mathrm{f}$ & $17.5 \mathrm{~b}-\mathrm{d}$ \\
\hline Average & $12.5 \mathrm{~B}+$ & $17.7 \mathrm{~A}$ & 15.1 \\
\hline
\end{tabular}

*Means with the same letter in a column are not statistically different from each other according to the Duncan test at $\mathrm{P} \leq 0.05$

+Means with the same letter in the row are not statistically different from each other at $\mathrm{P} \leq 0.05$

According to the averaged values over two years, the highest crude protein yield was obtained from the mixture of alfalfa + dallis grass. The crude protein yield of this mixture was statistically significant higher than those of all of pure growings and all of the mixtures with the exceptions of the mixtures of Bermuda grass + alfalfa, finger grass + alfalfa, Rhodes grass + alfalfa. 
Table 2. Crude protein yields $\left(\mathrm{kg} \mathrm{ha}^{-1}\right)$ of pure sowings and alfalfa-grass mixtures

\begin{tabular}{|c|c|c|c|}
\hline \multirow{2}{*}{ Mixture or pure sowing } & \multicolumn{2}{|c|}{ Years } & \multirow{2}{*}{ Average } \\
\hline & 2011 & 2012 & \\
\hline Bermuda grass (BG) & $1134.0 \mathrm{e}^{*}$ & $603.0 \mathrm{kl}$ & $868.5 \mathrm{j}$ \\
\hline Dallis grass (DG) & 1779.0 a-e & $826.0 \mathrm{kl}$ & $1302.5 \mathrm{ij}$ \\
\hline Rhodes grass (RG) & $1751.0 \mathrm{a}-\mathrm{e}$ & $1318.0 \mathrm{jk}$ & $1534.5 \mathrm{~h} 1$ \\
\hline Guinea grass (GG) & $1945.0 \mathrm{a}-\mathrm{d}$ & 241.01 & $1093.0 \mathrm{ij}$ \\
\hline Blue couch grass (BCG) & $1292.0 \mathrm{de}$ & $559.0 \mathrm{kl}$ & $925.5 \mathrm{j}$ \\
\hline Finger grass $(\mathrm{FG})$ & $1560.0 \mathrm{a}-\mathrm{e}$ & 408.01 & $984.0 \mathrm{j}$ \\
\hline Alfalfa (A) & $1608.0 \mathrm{a}-\mathrm{e}$ & $4514.0 \mathrm{c}-\mathrm{f}$ & $3061.0 \mathrm{~cd}$ \\
\hline $\mathrm{BG}+\mathrm{A}$ & $2019.0 \mathrm{a}-\mathrm{c}$ & $5685.0 \mathrm{ab}$ & $3852.0 \mathrm{a}$ \\
\hline $\mathrm{DG}+\mathrm{A}$ & $1927.0 \mathrm{a}-\mathrm{d}$ & $5970.0 \mathrm{a}$ & 3948.5 a \\
\hline $\mathrm{RG}+\mathrm{A}$ & $2223.0 \mathrm{a}$ & $4859.0 \mathrm{~b}-\mathrm{e}$ & $3541.0 \mathrm{a}-\mathrm{c}$ \\
\hline $\mathrm{GG}+\mathrm{A}$ & $1331.0 \mathrm{c}-\mathrm{e}$ & $3147.0 \mathrm{gh}$ & $2239.0 \mathrm{fg}$ \\
\hline $\mathrm{BCG}+\mathrm{A}$ & $1502.0 \mathrm{~b}-\mathrm{e}$ & $4384.0 \mathrm{c}-\mathrm{f}$ & $2943.0 \mathrm{de}$ \\
\hline $\mathrm{FG}+\mathrm{A}$ & $2140.0 \mathrm{ab}$ & $5053.0 \mathrm{~b}-\mathrm{d}$ & $3596.5 \mathrm{ab}$ \\
\hline $\mathrm{BG}+\mathrm{DG}+\mathrm{A}$ & 1748.0 a-e & $4500.0 \mathrm{c}-\mathrm{f}$ & $3124.0 \mathrm{~b}-\mathrm{d}$ \\
\hline $\mathrm{BG}+\mathrm{RG}+\mathrm{A}$ & $1622.0 \mathrm{a}-\mathrm{e}$ & $5060.0 \mathrm{~b}-\mathrm{d}$ & $3341.0 \mathrm{~b}-\mathrm{d}$ \\
\hline $\mathrm{BG}+\mathrm{GG}+\mathrm{A}$ & $1720.0 \mathrm{a}-\mathrm{e}$ & $2064.0 \mathrm{ij}$ & $1892.0 \mathrm{gh}$ \\
\hline $\mathrm{BG}+\mathrm{BCG}+\mathrm{A}$ & $1670.0 \mathrm{a}-\mathrm{e}$ & $4487.0 \mathrm{c}-\mathrm{f}$ & $3078.5 \mathrm{~cd}$ \\
\hline $\mathrm{BG}+\mathrm{FG}+\mathrm{A}$ & $1555.0 \mathrm{a}-\mathrm{e}$ & $4963.0 \mathrm{~b}-\mathrm{d}$ & $3259.0 \mathrm{~b}-\mathrm{d}$ \\
\hline $\mathrm{DG}+\mathrm{RG}+\mathrm{A}$ & $1966.0 \mathrm{a}-\mathrm{d}$ & 4733.0 c-e & $3349.5 \mathrm{~b}-\mathrm{d}$ \\
\hline $\mathrm{DG}+\mathrm{GG}+\mathrm{A}$ & $1938.0 \mathrm{a}-\mathrm{d}$ & $3758.0 \mathrm{fg}$ & $2848.0 \mathrm{de}$ \\
\hline $\mathrm{DG}+\mathrm{BCG}+\mathrm{A}$ & 1518.0 a-e & $5118.0 \mathrm{bc}$ & $3318.0 \mathrm{~b}-\mathrm{d}$ \\
\hline $\mathrm{DG}+\mathrm{FG}+\mathrm{A}$ & $1780.0 \mathrm{a}-\mathrm{e}$ & $4320.0 \mathrm{c}-\mathrm{f}$ & $3050.0 \mathrm{~cd}$ \\
\hline $\mathrm{RG}+\mathrm{GG}+\mathrm{A}$ & $1851.0 \mathrm{a}-\mathrm{d}$ & $3114.0 \mathrm{gh}$ & $2482.5 \mathrm{ef}$ \\
\hline $\mathrm{RG}+\mathrm{BCG}+\mathrm{A}$ & $1883.0 \mathrm{a}-\mathrm{d}$ & 4060.0 ef & $2971.5 \mathrm{de}$ \\
\hline $\mathrm{RG}+\mathrm{FG}+\mathrm{A}$ & $2081.0 \mathrm{ab}$ & $3806.0 \mathrm{fg}$ & $2943.5 \mathrm{de}$ \\
\hline $\mathrm{GG}+\mathrm{BCG}+\mathrm{A}$ & $1450.0 \mathrm{~b}-\mathrm{e}$ & $2697.0 \mathrm{~h} 1$ & $2073.5 \mathrm{fg}$ \\
\hline $\mathrm{GG}+\mathrm{FG}+\mathrm{A}$ & $1344.0 \mathrm{c}-\mathrm{e}$ & $2628.0 \mathrm{~h} 1$ & $1986.0 \mathrm{gh}$ \\
\hline $\mathrm{FG}+\mathrm{BCG}+\mathrm{A}$ & 1719.0 a-e & $4192.0 \mathrm{~d}-\mathrm{f}$ & $2955.5 \mathrm{de}$ \\
\hline Average & 1716.0 B+ & $3467.0 \mathrm{~A}$ & 2591.5 \\
\hline
\end{tabular}

*Means with the same letter in a column are not statistically different from each other according to the Duncan test at $\mathrm{P} \leq 0.05$

+ Means with the same letter in the row are not statistically different from each other at $\mathrm{P} \leq 0.05$

\section{$A D F$ and NDF ratios}

The results of the variance analysis showed that ADF and NDF contents of the dry matter were statistically significant influenced by pure sowing and mixtures as well as the years. Interaction of the years and treatments was also statistically significant. The averaged ADF content over the pure sowings and mixtures in the first year was significantly higher than those in the second year (Table 3). In the first year, contribution of the warm season grasses on the hay yield of the mixtures was higher than those in the second year. The grasses contain generally higher ADF than alfalfa 
(Linn and Martin, 1999). Therefore averaged ADF content of the dry matter in the first year was significantly higher than those in the second year.

In the first year and as the averaged values over the two years, alfalfa gave the dry matter with significantly lower ADF content than the other pure sowings and all of the mixtures. In the second year, alfalfa was the treatment among the treatments producing dry matter with low ADF content. In contrast to this, Guinea grass produced the dry matter with significantly higher ADF content than the other pure sowings and all of the mixtures in the second year and as the averaged values over the two years. It was among the treatments with high ADF content in the first year.

Table 3. ADF ratios (\%) of dry matters from pure sowings and alfalfa-grass mixtures

\begin{tabular}{|c|c|c|c|}
\hline \multirow{2}{*}{ Mixture or pure sowing } & \multicolumn{2}{|c|}{ Years } & \multirow{2}{*}{ Average } \\
\hline & 2011 & 2012 & \\
\hline Bermuda grass (BG) & $31.6 \mathrm{i}-\mathrm{k}^{*}$ & $32.1 \mathrm{c}-\mathrm{e}$ & 31.9 e-h \\
\hline Dallis grass $(\mathrm{DG})$ & $34.1 \mathrm{f}-\mathrm{h}$ & $34.8 \mathrm{~b}$ & $34.5 \mathrm{bc}$ \\
\hline Rhodes grass (RG) & $36.6 \mathrm{de}$ & $34.9 \mathrm{~b}$ & $35.8 \mathrm{~b}$ \\
\hline Guinea grass (GG) & $40.2 \mathrm{ab}$ & $39.2 \mathrm{a}$ & $39.7 \mathrm{a}$ \\
\hline Blue couch grass (BCG) & $31.1 \mathrm{jk}$ & $33.0 \mathrm{bc}$ & $32.1 \mathrm{e}-\mathrm{g}$ \\
\hline Finger grass $(\mathrm{FG})$ & $34.8 \mathrm{e}-\mathrm{g}$ & $32.9 \mathrm{~b}-\mathrm{d}$ & $33.8 \mathrm{~cd}$ \\
\hline Alfalfa (A) & $25.6 \mathrm{n}$ & $27.3 \mathrm{jk}$ & $26.5 n$ \\
\hline $\mathrm{BG}+\mathrm{A}$ & $28.6 \mathrm{~lm}$ & $29.2 \mathrm{f}-\mathrm{j}$ & $28.9 \mathrm{k}-\mathrm{m}$ \\
\hline $\mathrm{DG}+\mathrm{A}$ & $31.1 \mathrm{jk}$ & $29.2 \mathrm{f}-\mathrm{j}$ & $30.2 \mathrm{~h}-\mathrm{k}$ \\
\hline $\mathrm{RG}+\mathrm{A}$ & 35.5 ef & $29.5 \mathrm{f}-\mathrm{j}$ & $32.5 \mathrm{~d}-\mathrm{f}$ \\
\hline $\mathrm{GG}+\mathrm{A}$ & $41.0 \mathrm{a}$ & $28.01-\mathrm{k}$ & $34.5 \mathrm{bc}$ \\
\hline $\mathrm{BCG}+\mathrm{A}$ & $27.7 \mathrm{~m}$ & $28.21-\mathrm{k}$ & $28.0 \mathrm{mn}$ \\
\hline $\mathrm{FG}+\mathrm{A}$ & $29.7 \mathrm{k}-\mathrm{m}$ & $30.1 \mathrm{e}-1$ & $29.91-1$ \\
\hline $\mathrm{BG}+\mathrm{DG}+\mathrm{A}$ & $27.8 \mathrm{~m}$ & $28.9 \mathrm{~g}-\mathrm{j}$ & $28.4 \mathrm{~lm}$ \\
\hline $\mathrm{BG}+\mathrm{RG}+\mathrm{A}$ & $33.3 \mathrm{~g}-1$ & $29.7 \mathrm{f}-\mathrm{j}$ & $31.5 \mathrm{f}-1$ \\
\hline $\mathrm{BG}+\mathrm{GG}+\mathrm{A}$ & $38.6 \mathrm{bc}$ & $28.21-\mathrm{k}$ & $33.4 \mathrm{c}-\mathrm{e}$ \\
\hline $\mathrm{BG}+\mathrm{BCG}+\mathrm{A}$ & $28.6 \mathrm{~lm}$ & $29.8 \mathrm{e}-1$ & $29.2 \mathrm{j}-\mathrm{m}$ \\
\hline $\mathrm{BG}+\mathrm{FG}+\mathrm{A}$ & $29.9 \mathrm{kl}$ & $30.2 \mathrm{e}-1$ & $30.01-1$ \\
\hline $\mathrm{DG}+\mathrm{RG}+\mathrm{A}$ & 35.8 ef & $31.0 \mathrm{c}-\mathrm{g}$ & $33.4 \mathrm{c}-\mathrm{e}$ \\
\hline $\mathrm{DG}+\mathrm{GG}+\mathrm{A}$ & $39.5 \mathrm{a}-\mathrm{c}$ & $28.5 \mathrm{~h}-\mathrm{k}$ & $34.0 \mathrm{~cd}$ \\
\hline $\mathrm{DG}+\mathrm{BCG}+\mathrm{A}$ & $29.6 \mathrm{k}-\mathrm{m}$ & $30.7 \mathrm{~d}-\mathrm{h}$ & $30.1 \mathrm{~h}-\mathrm{k}$ \\
\hline $\mathrm{DG}+\mathrm{FG}+\mathrm{A}$ & $31.0 \mathrm{jk}$ & $31.5 \mathrm{c}-\mathrm{f}$ & $31.2 \mathrm{f}-1$ \\
\hline $\mathrm{RG}+\mathrm{GG}+\mathrm{A}$ & $39.3 \mathrm{a}-\mathrm{c}$ & $26.3 \mathrm{k}$ & $32.8 \mathrm{c}-\mathrm{f}$ \\
\hline $\mathrm{RG}+\mathrm{BCG}+\mathrm{A}$ & $32.6 \mathrm{~h}-\mathrm{j}$ & $28.8 \mathrm{~g}-\mathrm{j}$ & 30.7 g-j \\
\hline $\mathrm{RG}+\mathrm{FG}+\mathrm{A}$ & $34.4 \mathrm{f}-\mathrm{h}$ & $28.5 \mathrm{~h}-\mathrm{k}$ & $31.5 \mathrm{f}-1$ \\
\hline $\mathrm{GG}+\mathrm{BCG}+\mathrm{A}$ & $38.3 \mathrm{~b}-\mathrm{d}$ & $28.8 \mathrm{~g}-\mathrm{j}$ & $33.5 \mathrm{c}-\mathrm{e}$ \\
\hline $\mathrm{GG}+\mathrm{FG}+\mathrm{A}$ & $38.0 \mathrm{~cd}$ & $27.71-\mathrm{k}$ & $32.9 \mathrm{c}-\mathrm{f}$ \\
\hline $\mathrm{FG}+\mathrm{BCG}+\mathrm{A}$ & $28.5 \mathrm{~lm}$ & $29.4 \mathrm{f}-\mathrm{j}$ & $28.9 \mathrm{k}-\mathrm{m}$ \\
\hline Average & 33.3 A+ & $30.2 \mathrm{~B}$ & 31.8 \\
\hline
\end{tabular}

*Means with the same letter in a column are not statistically different from each other according to the Duncan test at $\mathrm{P} \leq 0.05$

+ Means with the same letter in the row are not statistically different from each other at $\mathrm{P} \leq 0.05$ 
The averaged NDF ratio of dry matter in the first year was significantly higher than those in the second year (Table 4). As mentioned above, higher grass ratio in the hay yield of the mixtures in the first year than that in the second year resulted in higher NDF content in the first year.

Table 4. NDF ratios (\%) of dry matters from pure sowings and alfalfa grass-mixtures

\begin{tabular}{|c|c|c|c|}
\hline \multirow{2}{*}{ Mixture or pure sowing } & \multicolumn{2}{|c|}{ Years } & \multirow{2}{*}{ Average } \\
\hline & 2011 & 2012 & \\
\hline Bermuda grass (BG) & $64.9 \mathrm{bc}^{*}$ & $62.7 \mathrm{c}$ & $63.8 \mathrm{~b}$ \\
\hline Dallis grass $(\mathrm{DG})$ & $63.4 \mathrm{~b}-\mathrm{d}$ & $64.8 \mathrm{bc}$ & $64.1 \mathrm{~b}$ \\
\hline Rhodes grass (RG) & $67.2 \mathrm{ab}$ & $66.7 \mathrm{ab}$ & $67.0 \mathrm{a}$ \\
\hline Guinea grass (GG) & $68.5 \mathrm{ab}$ & $68.2 \mathrm{a}$ & $68.3 \mathrm{a}$ \\
\hline Blue couch grass (BCG) & $63.6 \mathrm{~b}-\mathrm{d}$ & $62.6 \mathrm{c}$ & $63.1 \mathrm{~b}$ \\
\hline Finger grass $(\mathrm{FG})$ & $63.3 \mathrm{~b}-\mathrm{d}$ & $60.0 \mathrm{~d}$ & $61.7 \mathrm{~b}$ \\
\hline Alfalfa (A) & $36.4 \mathrm{~h}$ & 38.21 & $37.3 \mathrm{k}$ \\
\hline $\mathrm{BG}+\mathrm{A}$ & $49.9 \mathrm{e}-\mathrm{g}$ & $40.8 \mathrm{~g}-\mathrm{k}$ & $45.3 \mathrm{~h}-\mathrm{j}$ \\
\hline $\mathrm{DG}+\mathrm{A}$ & 52.9 ef & $40.4 \mathrm{~h}-1$ & $46.7 \mathrm{~h} 1$ \\
\hline $\mathrm{RG}+\mathrm{A}$ & $64.8 \mathrm{bc}$ & 40.4 h-1 & $52.6 \mathrm{c}-\mathrm{f}$ \\
\hline $\mathrm{GG}+\mathrm{A}$ & $70.0 \mathrm{a}$ & $38.7 \mathrm{kl}$ & $54.3 \mathrm{~cd}$ \\
\hline $\mathrm{BCG}+\mathrm{A}$ & $48.5 \mathrm{fg}$ & $39.2 \mathrm{j}-1$ & $43.9 \mathrm{ij}$ \\
\hline $\mathrm{FG}+\mathrm{A}$ & $46.7 \mathrm{~g}$ & $40.5 \mathrm{~g}-1$ & $43.6 \mathrm{j}$ \\
\hline $\mathrm{BG}+\mathrm{DG}+\mathrm{A}$ & $50.6 \mathrm{e}-\mathrm{g}$ & $40.6 \mathrm{~g}-1$ & $45.6 \mathrm{~h}-\mathrm{j}$ \\
\hline $\mathrm{BG}+\mathrm{RG}+\mathrm{A}$ & $61.6 \mathrm{~cd}$ & $41.7 \mathrm{e}-\mathrm{j}$ & $51.7 \mathrm{~d}-\mathrm{f}$ \\
\hline $\mathrm{BG}+\mathrm{GG}+\mathrm{A}$ & $67.1 \mathrm{ab}$ & $41.9 \mathrm{e}-1$ & $54.5 \mathrm{~cd}$ \\
\hline $\mathrm{BG}+\mathrm{BCG}+\mathrm{A}$ & $51.7 \mathrm{ef}$ & $40.4 \mathrm{~h}-1$ & $46.1 \mathrm{~h}-\mathrm{j}$ \\
\hline $\mathrm{BG}+\mathrm{FG}+\mathrm{A}$ & $53.9 \mathrm{e}$ & $41.4 \mathrm{f}-\mathrm{j}$ & $47.6 \mathrm{gh}$ \\
\hline $\mathrm{DG}+\mathrm{RG}+\mathrm{A}$ & $64.5 \mathrm{~b}-\mathrm{d}$ & $43.8 \mathrm{ef}$ & $54.2 \mathrm{~cd}$ \\
\hline $\mathrm{DG}+\mathrm{GG}+\mathrm{A}$ & $67.9 \mathrm{ab}$ & $42.1 \mathrm{e}-1$ & $55.0 \mathrm{c}$ \\
\hline $\mathrm{DG}+\mathrm{BCG}+\mathrm{A}$ & $51.3 \mathrm{e}-\mathrm{g}$ & $43.0 \mathrm{e}-\mathrm{g}$ & $47.2 \mathrm{~h}$ \\
\hline $\mathrm{DG}+\mathrm{FG}+\mathrm{A}$ & $49.2 \mathrm{e}-\mathrm{g}$ & $44.2 \mathrm{e}$ & $46.7 \mathrm{~h} 1$ \\
\hline $\mathrm{RG}+\mathrm{GG}+\mathrm{A}$ & $68.3 \mathrm{ab}$ & $38.8 \mathrm{kl}$ & $53.5 \mathrm{c}-\mathrm{e}$ \\
\hline $\mathrm{RG}+\mathrm{BCG}+\mathrm{A}$ & $59.6 \mathrm{~d}$ & $41.8 \mathrm{e}-\mathrm{j}$ & 50.7 ef \\
\hline $\mathrm{RG}+\mathrm{FG}+\mathrm{A}$ & $60.8 \mathrm{~cd}$ & $39.51-1$ & $50.2 \mathrm{fg}$ \\
\hline $\mathrm{GG}+\mathrm{BCG}+\mathrm{A}$ & $65.3 \mathrm{a}-\mathrm{c}$ & $42.0 \mathrm{e}-1$ & $53.7 \mathrm{c}-\mathrm{e}$ \\
\hline $\mathrm{GG}+\mathrm{FG}+\mathrm{A}$ & $67.1 \mathrm{ab}$ & $38.7 \mathrm{kl}$ & $52.9 \mathrm{c}-\mathrm{f}$ \\
\hline $\mathrm{FG}+\mathrm{BCG}+\mathrm{A}$ & $52.6 \mathrm{ef}$ & $42.7 \mathrm{e}-\mathrm{h}$ & $47.7 \mathrm{gh}$ \\
\hline Average & $59.0 \mathrm{~A}+$ & 45.9 B & 52.5 \\
\hline
\end{tabular}

*Means with the same letter in a column are not statistically different from each other according to the Duncan test at $\mathrm{P} \leq 0.05$

+Means with the same letter in the row are not statistically different from each other at $\mathrm{P} \leq 0.05$

\section{Digestible dry matter content}

The results of the variance analysis showed that the digestible dry matter ratio was influenced by pure sowings and mixtures as well as years. Year $\mathrm{x}$ treatment interaction 
was also statistically significant. Averaged digestible dry matter ratios in the second year were significantly higher than that in the first year (Table 5).

The digestible dry matter ratio is calculated using the ADF values and is inversely proportional. ADF ratios are higher in the second year than in the first year. Therefore, the rate of digestible dry matter in the second year is higher than in the first year.

In the first year, digestible dry matter ratio of alfalfa was significantly higher than those of the other pure sowings and all of the mixtures with the exception of BCG+A and $\mathrm{BG}+\mathrm{DG}+\mathrm{A}$ (Table 5). Pure sowing of Guinea grass produced dry matter with significantly lower digestibility ratio than the other pure sowings and all of the mixtures with the exceptions of the mixtures containing Guinea grass.

Table 5. Digestible dry matter ratios (\%) of dry matters from pure sowings and alfalfa-grass mixtures

\begin{tabular}{|c|c|c|c|}
\hline \multirow{2}{*}{ Mixture or pure sowing } & \multicolumn{2}{|c|}{ Years } & \multirow{2}{*}{ Average } \\
\hline & 2011 & 2012 & \\
\hline Bermuda grass (BG) & $64.3 \mathrm{c}-\mathrm{h}^{*}$ & $63.9 \mathrm{~g}-1$ & $64.1 \mathrm{f}-\mathrm{k}$ \\
\hline Dallis grass (DG) & $62.3 \mathrm{~g}-\mathrm{k}$ & $61.8 \mathrm{j}$ & $62.1 \mathrm{mn}$ \\
\hline Rhodes grass (RG) & 60.4 k-n & $61.7 \mathrm{j}$ & $61.0 \mathrm{n}$ \\
\hline Guinea grass (GG) & $57.6 \mathrm{o}$ & $58.4 \mathrm{k}$ & $58.0 \mathrm{o}$ \\
\hline Blue couch grass (BCG) & $64.7 \mathrm{c}-\mathrm{g}$ & $63.2 \mathrm{ij}$ & $63.9 \mathrm{~g}-1$ \\
\hline Finger grass (FG) & $61.81-\mathrm{k}$ & $63.3 \mathrm{~h}-\mathrm{j}$ & $62.6 \mathrm{k}-\mathrm{n}$ \\
\hline Alfalfa (A) & $69.0 \mathrm{a}$ & $67.6 \mathrm{ab}$ & $68.3 \mathrm{a}$ \\
\hline $\mathrm{BG}+\mathrm{A}$ & $66.6 \mathrm{bc}$ & $66.2 \mathrm{~b}-\mathrm{f}$ & $66.4 \mathrm{~b}-\mathrm{d}$ \\
\hline $\mathrm{DG}+\mathrm{A}$ & $64.7 \mathrm{c}-\mathrm{g}$ & $66.2 \mathrm{~b}-\mathrm{f}$ & $65.4 \mathrm{c}-\mathrm{g}$ \\
\hline $\mathrm{RG}+\mathrm{A}$ & $61.21-1$ & $65.9 \mathrm{~b}-\mathrm{f}$ & $63.6 \mathrm{~h}-\mathrm{m}$ \\
\hline $\mathrm{GG}+\mathrm{A}$ & $57.0 \mathrm{o}$ & $67.1 \mathrm{a}-\mathrm{c}$ & $62.0 \mathrm{mn}$ \\
\hline $\mathrm{BCG}+\mathrm{A}$ & $67.3 \mathrm{ab}$ & $66.9 \mathrm{a}-\mathrm{d}$ & $67.1 \mathrm{ab}$ \\
\hline $\mathrm{FG}+\mathrm{A}$ & $65.8 \mathrm{~b}-\mathrm{e}$ & $65.5 \mathrm{c}-\mathrm{g}$ & $65.6 \mathrm{~b}-\mathrm{f}$ \\
\hline $\mathrm{BG}+\mathrm{DG}+\mathrm{A}$ & $67.3 \mathrm{ab}$ & $66.3 \mathrm{~b}-\mathrm{e}$ & $66.8 \mathrm{bc}$ \\
\hline $\mathrm{BG}+\mathrm{RG}+\mathrm{A}$ & $63.0 \mathrm{f}-\mathrm{j}$ & $65.8 \mathrm{~b}-\mathrm{f}$ & $64.4 \mathrm{f}-\mathrm{j}$ \\
\hline $\mathrm{BG}+\mathrm{GG}+\mathrm{A}$ & $58.9 \mathrm{~m}-\mathrm{o}$ & $66.9 \mathrm{a}-\mathrm{d}$ & $62.9 \mathrm{j}-\mathrm{m}$ \\
\hline $\mathrm{BG}+\mathrm{BCG}+\mathrm{A}$ & $66.6 \mathrm{bc}$ & $65.6 \mathrm{c}-\mathrm{g}$ & $62.41-n$ \\
\hline $\mathrm{BG}+\mathrm{FG}+\mathrm{A}$ & $65.6 \mathrm{~b}-\mathrm{e}$ & $65.4 \mathrm{c}-\mathrm{g}$ & $66.1 \mathrm{~b}-\mathrm{e}$ \\
\hline $\mathrm{DG}+\mathrm{RG}+\mathrm{A}$ & $61.1 \mathrm{j}-\mathrm{m}$ & $64.8 \mathrm{e}-1$ & $65.5 \mathrm{c}-\mathrm{g}$ \\
\hline $\mathrm{DG}+\mathrm{GG}+\mathrm{A}$ & $58.1 \mathrm{no}$ & $66.7 \mathrm{a}-\mathrm{e}$ & $62.9 \mathrm{j}-\mathrm{m}$ \\
\hline $\mathrm{DG}+\mathrm{BCG}+\mathrm{A}$ & $65.9 \mathrm{~b}-\mathrm{d}$ & $65.0 \mathrm{~d}-\mathrm{h}$ & $62.41-n$ \\
\hline $\mathrm{DG}+\mathrm{FG}+\mathrm{A}$ & $64.8 \mathrm{c}-\mathrm{f}$ & $64.4 \mathrm{f}-1$ & $65.4 \mathrm{c}-\mathrm{g}$ \\
\hline $\mathrm{RG}+\mathrm{GG}+\mathrm{A}$ & 58.3 no & $68.4 \mathrm{a}$ & $64.6 \mathrm{e}-1$ \\
\hline $\mathrm{RG}+\mathrm{BCG}+\mathrm{A}$ & $63.5 \mathrm{~d}-1$ & $66.5 \mathrm{~b}-\mathrm{e}$ & $63.41-\mathrm{m}$ \\
\hline $\mathrm{RG}+\mathrm{FG}+\mathrm{A}$ & $62.1 \mathrm{~h}-\mathrm{k}$ & $66.7 \mathrm{a}-\mathrm{e}$ & $65.0 \mathrm{~d}-\mathrm{h}$ \\
\hline $\mathrm{GG}+\mathrm{BCG}+\mathrm{A}$ & $59.11-0$ & $66.5 \mathrm{~b}-\mathrm{e}$ & $64.4 \mathrm{f}-\mathrm{j}$ \\
\hline $\mathrm{GG}+\mathrm{FG}+\mathrm{A}$ & $59.31-0$ & $67.3 \mathrm{a}-\mathrm{c}$ & $62.8 \mathrm{j}-\mathrm{m}$ \\
\hline $\mathrm{FG}+\mathrm{BCG}+\mathrm{A}$ & $63.4 \mathrm{e}-\mathrm{j}$ & $65.9 \mathrm{~b}-\mathrm{f}$ & $64.6 \mathrm{e}-1$ \\
\hline Average & $62.8 \mathrm{~B}+$ & $65.3 \mathrm{~A}$ & 64.1 \\
\hline
\end{tabular}

*Means with the same letter in a column are not statistically different from each other according to the Duncan test at $\mathrm{P} \leq 0.05$

+Means with the same letter in the row are not statistically different from each other at $\mathrm{P} \leq 0.05$ 
In the second year, the mixture of $\mathrm{RG}+\mathrm{GG}+\mathrm{A}$ produced the dry matter with significantly higher digestibility ratio than all of the pure sowings with the exception of alfalfa and all of the mixtures with the exceptions of $\mathrm{GG}+\mathrm{A}, \mathrm{GG}+\mathrm{FG}+\mathrm{A}, \mathrm{BCG}+\mathrm{A}$, $\mathrm{BG}+\mathrm{GG}+\mathrm{A}, \mathrm{DG}+\mathrm{GG}+\mathrm{A}$ and $\mathrm{RG}+\mathrm{FG}+\mathrm{A}$ All of the pure sowings of the grasses gave the dry matter with significantly lower digestibility ratio than the pure sowing of alfalfa.

Some of our findings are consistent with those above mentioned, some of them are incompatible. The differences between our finding and that of previous studies could be due to the ecological differences, varieties, mixes, practices applied.

\section{Relative feed value (RFV)}

The results of the variance analysis showed that RFV was statistically significant influenced by pure sowings and mixtures as well as years. Year $\mathrm{x}$ mixture interaction was also statistically significant. The averaged RFV over the pure sowings and mixtures significantly changed depending on the years. The averaged RFV in the second year was significantly higher than those in first year (Table 6). The higher alfalfa contribution to the hay yield of the mixtures in the second year as compared to the first year resulted in higher RFV in second year. RFV is inversely proportional to the ADF and NDF. Therefore higher averaged RFVs were obtained in the second year in which ratios of NDF and ADF were lower than those in the first year.

In the first year of the experiment and as averaged value over the years, pure sown alfalfa produced the dry matter with significantly higher RFV than the other pure sowings and all of the mixtures. In the second year, the mixtures of DG+A, $\mathrm{RG}+\mathrm{A}, \mathrm{GG}+\mathrm{A}, \mathrm{BCG}+\mathrm{A}, \mathrm{RG}+\mathrm{GG}+\mathrm{A}, \mathrm{RG}+\mathrm{FG}+\mathrm{A}$ and $\mathrm{GG}+\mathrm{FG}+\mathrm{A}$ gave dry matters with RFVs being not statistically significant different from that of Alfalfa dry matter.

\section{Discussion}

It was determined that crude protein content of pure growing alfalfa was significantly higher than those of pure growing grasses and generally higher than the mixtures of grasses with alfalfa. Previous studies have also shown that alfalfa contains significantly more protein than grasses and that grass+legume mixtures contain more crude protein than the pure sowing grasses (Spandl and Hesterman, 1997; Avci, 2000; Albayrak and Ekiz, 2005; Cinar and Hatipoglu, 2014).

Nutrient value of a mixture forage relatively depends on the botanical composition and harvesting time. The results indicated that $\mathrm{CP}$ contents of dry matter of the mixtures were generally lower than $16-18 \%$ which requires supplementary feeding to obtain high performance from milk cows (Baytekin and Gul, 2009).

According to the two years averaged values, alfalfa gave significantly higher crude protein yield than the pure growing grasses. Conrad and Martz (1985), Rohweder and Keuren (1985), Spandl and Hesterman (1997) reported also that alfalfa has higher dry matter and crude protein yield than grasses. Some of the duo mixture of grasses with alfalfa such as $\mathrm{BG}+\mathrm{A}, \mathrm{DG}+\mathrm{A}$ and $\mathrm{FG}+\mathrm{A}$ produced significantly higher crude protein yield than pure growing alfalfa. This was due to the higher dry matter yields of those mixtures. This result was consistent with that of Albayrak and Turk (2011). 
Table 6. RFVs of pure sowings and alfalfa-grass mixtures

\begin{tabular}{|c|c|c|c|}
\hline \multirow{2}{*}{ Mixture or pure sowing } & \multicolumn{2}{|c|}{ Years } & \multirow{2}{*}{ Average } \\
\hline & 2011 & 2012 & \\
\hline Bermuda grass (BG) & $92.2 \mathrm{e}-\mathrm{h} *$ & $94.8 \mathrm{j}$ & $93.5 \mathrm{k}$ \\
\hline Dallis grass (DG) & $91.5 \mathrm{e}-\mathrm{h}$ & $88.6 \mathrm{j}$ & $90.1 \mathrm{k}$ \\
\hline Rhodes grass (RG) & $83.7 \mathrm{f}-\mathrm{j}$ & 64.51 & 74.11 \\
\hline Guinea grass (GG) & $78.2 \mathrm{ij}$ & $79.7 \mathrm{k}$ & 78.91 \\
\hline Blue couch grass (BCG) & $94.7 \mathrm{e}-\mathrm{g}$ & $94.0 \mathrm{j}$ & $94.3 \mathrm{k}$ \\
\hline Finger grass $(\mathrm{FG})$ & $90.8 \mathrm{e}-1$ & $98.1 \mathrm{j}$ & $94.5 \mathrm{k}$ \\
\hline Alfalfa (A) & $176.5 \mathrm{a}$ & $165.1 \mathrm{a}$ & $170.8 \mathrm{a}$ \\
\hline $\mathrm{BG}+\mathrm{A}$ & $124.5 \mathrm{~b}-\mathrm{d}$ & $151.0 \mathrm{~b}-\mathrm{h}$ & $137.8 \mathrm{~b}-\mathrm{d}$ \\
\hline $\mathrm{DG}+\mathrm{A}$ & $113.7 \mathrm{~d}$ & $152.3 \mathrm{a}-\mathrm{g}$ & $133.0 \mathrm{c}-\mathrm{f}$ \\
\hline $\mathrm{RG}+\mathrm{A}$ & $88.1 \mathrm{e}-\mathrm{j}$ & $152.0 \mathrm{a}-\mathrm{g}$ & $120.0 \mathrm{~g}-\mathrm{j}$ \\
\hline $\mathrm{GG}+\mathrm{A}$ & $75.8 \mathrm{j}$ & $161.3 \mathrm{a}-\mathrm{d}$ & $118.6 \mathrm{~h}-\mathrm{j}$ \\
\hline $\mathrm{BCG}+\mathrm{A}$ & $129.7 \mathrm{bc}$ & 159.3 a-e & $144.5 \mathrm{~b}$ \\
\hline $\mathrm{FG}+\mathrm{A}$ & $131.5 \mathrm{~b}$ & $150.4 \mathrm{~b}-\mathrm{h}$ & $141.0 \mathrm{bc}$ \\
\hline $\mathrm{BG}+\mathrm{DG}+\mathrm{A}$ & $124.0 \mathrm{~b}-\mathrm{d}$ & $145.6 \mathrm{e}-1$ & $134.8 \mathrm{~b}-\mathrm{e}$ \\
\hline $\mathrm{BG}+\mathrm{RG}+\mathrm{A}$ & $95.5 \mathrm{ef}$ & $146.9 \mathrm{e}-1$ & $121.2 \mathrm{~g}-\mathrm{j}$ \\
\hline $\mathrm{BG}+\mathrm{GG}+\mathrm{A}$ & $81.6 \mathrm{~g}-\mathrm{j}$ & $148.6 \mathrm{c}-1$ & $115.1 \mathrm{j}$ \\
\hline $\mathrm{BG}+\mathrm{BCG}+\mathrm{A}$ & $121.1 \mathrm{~b}-\mathrm{d}$ & $151.4 \mathrm{a}-\mathrm{h}$ & $136.3 \mathrm{~b}-\mathrm{e}$ \\
\hline $\mathrm{BG}+\mathrm{FG}+\mathrm{A}$ & $113.5 \mathrm{~d}$ & $147.2 \mathrm{e}-1$ & $130.4 \mathrm{c}-\mathrm{g}$ \\
\hline $\mathrm{DG}+\mathrm{RG}+\mathrm{A}$ & $88.0 \mathrm{e}-\mathrm{j}$ & 137.7 hı & $112.9 \mathrm{j}$ \\
\hline $\mathrm{DG}+\mathrm{GG}+\mathrm{A}$ & $79.7 \mathrm{~h}-\mathrm{j}$ & $147.3 \mathrm{e}-1$ & $113.5 \mathrm{j}$ \\
\hline $\mathrm{DG}+\mathrm{BCG}+\mathrm{A}$ & $120.0 \mathrm{~b}-\mathrm{d}$ & $140.7 \mathrm{~g}-1$ & $130.4 \mathrm{c}-\mathrm{g}$ \\
\hline $\mathrm{DG}+\mathrm{FG}+\mathrm{A}$ & $122.9 \mathrm{~b}-\mathrm{d}$ & 135.61 & $129.3 \mathrm{~d}-\mathrm{h}$ \\
\hline $\mathrm{RG}+\mathrm{GG}+\mathrm{A}$ & 79.4 h-j & $164.3 \mathrm{ab}$ & $121.8 \mathrm{~g}-\mathrm{j}$ \\
\hline $\mathrm{RG}+\mathrm{BCG}+\mathrm{A}$ & $99.1 \mathrm{e}$ & $148.0 \mathrm{~d}-1$ & $123.6 \mathrm{f}-\mathrm{j}$ \\
\hline $\mathrm{RG}+\mathrm{FG}+\mathrm{A}$ & 95.4 ef & 157.0 a-f & $126.2 \mathrm{e}-1$ \\
\hline $\mathrm{GG}+\mathrm{BCG}+\mathrm{A}$ & $84.1 \mathrm{f}-\mathrm{j}$ & $147.1 \mathrm{e}-1$ & $115.6 \mathrm{ij}$ \\
\hline $\mathrm{GG}+\mathrm{FG}+\mathrm{A}$ & $82.4 \mathrm{f}-\mathrm{j}$ & $162.3 \mathrm{a}-\mathrm{c}$ & $122.3 \mathrm{f}-\mathrm{j}$ \\
\hline $\mathrm{FG}+\mathrm{BCG}+\mathrm{A}$ & $118.0 \mathrm{~cd}$ & $143.5 \mathrm{f}-1$ & $130.8 \mathrm{c}-\mathrm{g}$ \\
\hline Average & $102.7 \mathrm{~B}+$ & $136.9 \mathrm{~A}$ & 119.8 \\
\hline
\end{tabular}

*Means with the same letter in a column are not statistically different from each other according to the Duncan test at $\mathrm{P} \leq 0.05$

+Means with the same letter in the row are not statistically different from each other at $\mathrm{P} \leq 0.05$

In the study, alfalfa gave the dry matter with significantly lower ADF and NDF contents than the other pure sowings and generally lower than those of all of the mixtures. In contrast to this, Guinea grass produced the dry matter with significantly higher ADF and NDF contents than the other pure sowings and all of the mixtures. The reasons of the higher ADF and NDF contents of Guinea grass could be development stage of the plant at the harvest (Anonymous, 2012) as well as the lower leaf- stem ratio (Pinkerton and Cross, 1992). The ADF concentration refers to the cell wall portion of the forage. The portion consist of cellulose and lignin. The ADF value is important because it describes the ability of an animal to digest the forage. As the ADF increases, the digestibility of the forage usually decreases. The NDF value refers to the total cell 
wall, composed of the ADF fraction plus hemicellulose. NDF value is important in ration formulation because it reflects the amount of forage that the animal can consume. As the NDF percentage increases, the dry matter intake will generally decrease (Joachim and Jung, 1997; Albayrak et al., 2011). Horner et al. (1985) determined ADF content of alfalfa as $35.3-41.1 \%$ while Cassida et al. (2000) reported it as $29.7-33.5 \%$. ADF content of the mixture of Rhodes grass + white sweet clover was reported by Corletto et al. (2009) as 37.0\%. Horner et al. (1985) determined NDF content of alfalfa as $46.0 \%$ while Cassida et al. (2000) reported it as 37.8 - 42.0\%. Jeranyama and Garcia (2004) reported a NDF value of $54 \%$ for the mixture of alfalfa + grasses of mixtures. Tessema and Baars (2006) determined NDF values for Rhodes grass and for the mixture of alfalfa + Rhodes grass as $55.7 \%$ and $46.9 \%$, respectively. Lemus (2009) reported a NDF value of $67.2-67.6 \%$ for dallis grass. Cinar et al. (2014) reported a ADF, NDF value of the $40.2 \%, 70.9 \%$ for dallis grass respectively.

Some of our findings are consistent with those above mentioned, some of them are incompatible. Differences between the findings may be due to differences in climatic conditions, under which researches were conducted, and management techniques applied in the experimental plots (Linn and Martin, 1999; Belyea et al., 1999; Bani et al., 2007).

According to the averaged values over two years, the highest digestible dry matter ratio was obtained from pure sown alfalfa. It was significantly higher than those of all of the other pure sowings and all of the mixtures with the exception of the mixture $\mathrm{BCG}+\mathrm{A}$. Pure sowings of Guinea grass produced the dry matter with significantly lower digestibility ratio than the other pure sowings and mixtures. Alfalfa's ADF content is lower than those of grasses. As the proportion of alfalfa in the mixture increases, the ADF ratio decreases and the digestibility increases (Joachim and Jung, 1997; Cinar and Hatipoglu, 2014). Felicity et al. (1996) determined DDM content of dallis grass as 63.6\% while Cook et al. (2005) 57.0-63.0\%. Cinar and Hatipoglu (2014) reported DDM ratio values of alfalfa, dallis grass, Bermuda grass, Rhodes grass, DG+A, BG+A, $\mathrm{RG}+\mathrm{A}, \mathrm{RG}+\mathrm{DG}+\mathrm{A}, \mathrm{BG}+\mathrm{DG}+\mathrm{A}, \mathrm{RG}+\mathrm{BG}+\mathrm{A} 68.1 \%, 57.6 \%, 63.1 \%, 60.7 \%, 63.0 \%$, $66.3 \%, 63.4 \%, 62.6 \%, 65.1 \%, 63.1 \%$ respectively.

Relative feed value (RFV) has been used for years to compare the quality of legume and legume/grass hays and silages. Having one index to price hay and predict animal performance has been very useful for livestock producers and hay farmers. Forages with an RFV value over 151, between 150-125, 124-103, 102-87, 86-75, and less than 75 are categorized as prime, premium, good, fair, poor and rejected, respectively (Kiraz, 2011; Uzun, 2010; Cinar et al., 2014). According to these index values, hay of pure sowing alfalfa is classified as prime while hays of the mixtures of Bermuda grass+alfalfa, dallis grass+alfalfa, blue couch grass+alfalfa, finger grass+alfalfa, Bermuda grass+dallis grass+alfalfa, Bermuda grass+blue couch grass+alfalfa, Bermuda grass+finger grass+alfalfa, dallis grass+blue couch grass+alfalfa, dallis grass+finger grass+alfalfa, Rhodes grass+finger grass+alfalfa, finger grass+blue couch grass+alfalfa are classified as premium.

\section{Conclusions}

It was concluded that, the mixtures of Bermuda grass+alfalfa, dallis grass+alfalfa, blue couch grass+alfalfa, finger grass+alfalfa, Bermuda grass+finger grass+alfalfa, dallis grass+blue couch grass+alfalfa, dallis grass+finger grass+alfalfa, Bermuda 
grass+dallis grass+alfalfa, Rhodes grass+finger grass+alfalfa and finger grass+blue couch grass+alfalfa could be grown for the feeding of high yielding dairy cows in Mediterranean climatical conditions. On the other hand, additional researches on the seed mixture ratios, fertilization and harvest time should be conducted in order to increase the forage quality of the mentioned mixtures.

\section{REFERENCES}

[1] Aganoglu, V. (1985): A research on the possibility of growing Rhodes grass (Chloris gayana Kunth) and alfalfa (Medivago sativa L.) in mixture under Cukurova conditions. Msc Thesis, Field Crops Department of Institute for Natural and Applied Sciences, Cukurova University, Adana.

[2] Albayrak, S., Ekiz, H. (2005): An investigation on the establishment of artificial pasture under Ankara's ecological conditions. - Turk J Agric For 29: 69-74.

[3] Albayrak, S., Türk, M. (2011): Effects of fertilization on forage yield and quality of crested wheatgrass (Agropyron cristatum L. Gaertn.). - Bulgarian Journal of Agricultural Science 17(5): 642-648.

[4] Albayrak, S., Turk, M., Yuksel, O. Yilmaz, M. (2011): Forage yield and the quality of perennial legume-grass mixtures under rainfed conditions. - Notulae Botanicae Horti Agrobotanici Cluj 39(1): 114-118.

[5] Anonymous (2011): Chemical Analysis Results. - University of Cukurova Laboratory of Soil Science, Faculty of Agriculture, Adana, Turkey.

[6] Anonymous (2012): Paspalum dilatatum Poir. - www.tropicalforages.info (accessed January 10, 2012).

[7] Anonymous (2013): Meteorological data for Adana. - http://www.wunderground.com (accessed December 12, 2014).

[8] Avci, M. (2000): Determining Suitable Mixtures of Cool Season Perennial Grasses and Legumes for Establishment of Short Term Pastures in Cukurova Region. - Department of Field Crops, Institute of Natural and Applied Sciences, Cukurova University, Adana.

[9] Aydin, N., Mut, Z., Mut, H., Ayan, İ. (2010): Effect of autumn and spring sowing dates on hay yield and quality of oat (Avena sativa L.) genotypes. - Journal of Animal and Veterinary Advances 9(10): 1539-1545.

[10] Bani, P., Minuti, A., Luraschi, A. O., Ligabue, M., Ruozzi, F. (2007): Genetic and Enviromental Influences on In Vitro Digestibility of Alfalfa. - Italian Journal of Animal Science 6(1): 251-253.

[11] Baytekin, H., Gül, İ. (2009): Forage Crops Harvest, Hay Yield and Storage. - In: Avcioğlu, R., Hatipoğlu, R., Karadağ, Y. (eds.) Forage. Cilt III. TÜGEM, Emre p, İzmir, pp. 121-141.

[12] Belyea, R., Restrepo, R., Martz, F., Ellersieck, M. (1999): Effect of year and cutting on equations for estimating net energy of alfalfa. - Journal of Dairy Science 82(9): 19431949.

[13] Blanchet, K. M., George, J. R., Gettle, R. M., Buxton, D. R., Moore, K. J. (1995): Establishment and persistence of legumes interseeded into switchgrass. - Agron. J. 87: 935-941.

[14] Cameron, A. G., Lemcke, B. (2010): Pasture species sowing guide for the top end. http://www.nt.gov.au/d/Content/File/p/Pasture/544.pdf (accessed April 20, 2014).

[15] Cassida, K. A., Griffin, T. S., Rodriguez, J., Patching, S. C., Hesterman, O. B., Rust, S. R. (2000): Protein degradability and forage quality in maturing alfalfa, red clover and birdsfoot trefoil. - Crop Science 40: 209-215. 
[16] Cinar, S., Hatipoğlu, R. (2014): Quality characteristics of the mixtures of some warm season perennial grasses with alfalfa Medicago sativa L. under irrigated conditions of Cukurova. - Turkish Journal of Field Crops 20(1): 31-37.

[17] Cinar, S. Hatipoğlu, R., Gundel, F., Aktaş, A., Avci, M. (2014): Performances of Some Perennial Warm Season Grasses Alfalfa Medicago sativa L Mixtures Under Mediterranean Conditions Turkish Journal of Field Crops. - Turkish Journal of Field Crops 19(2): 212-218.

[18] Conrad, H. R., Martz, F. A. (1985): Forages for Dairy Cattle. - In: Heath, E., Barns, F., Metcalfe, S. (eds.) Forages. Iowa State University Press, Iowa, pp. 550-559.

[19] Cook, B. G., Pengelly. B. C., Brown, S. D., Donnelly, J. I., Eagles, D. A., Franco, M. A., Hanson, J, Mullen. B. F., Partrıdge, I. J., Peters, M., Schultze Kraft, R. (2005): Tropical Forages: an Interactive Selection Tool. - CSIRO, DPI \& F (Qld), CIAT and ILRI, Brisbane, Australia.

[20] Corletto, A., Cazzato, E., Ventricelli, P., Cesentino, S. L., Gresta, F., Testa, G., Maiorana, M., Fornaro, F., De Giorgio, D. (2009): Performance of perennial tropical grasses in different mediterannean environments in southern Italy. - Tropical Grasslands 43: 129138. www.tropicalgrasslands.asn.au/.

[21] Felicity, S. J., Mcnabb, W. C., Peters, J. S., Barry, T. N., Campbell, B. D., Ulyatt, M. J. (1996): Nutritive value of subtropical grasses invading North Island pastures. Proceedings of the New Zealand Grassland Association 57: 203-206.

[22] Gettle, R. M., George, J. R., Blanchet, K. M., Buxton, D. R., Moore, K. J. (1996): Frostseeding legumes into established switchgrass. Establishment, density, persistence, and sward composition. - Agron. J. 88: 98-103.

[23] Horner, L. J., Bush, J., Adams, G. D., Taliaferro, C. M. (1985): Comparative nutritional value of eastern gama grass and alfalfa hay for dairy cows. - Journal of Dairy Science 68: $15-26$.

[24] Hoy, M. D., Moore, K. J., George, J. R., Brummer, E. E. (2002): Alfalfa yield and quality as influenced by establishment method. - Agron. J. 94: 65-71.

[25] Jeranyama, P., Garcia, A. (2004): Understanding relative feed value (RFV) and relative forage quality (RFQ).

http://pubstorage.sdstate.edu/AgBio_Publications/articles/ExEx8149.pdf (accessed May 20, 2014).

[26] Joachim, H., Jung, G. (1997): Analysis of forage fiber and cell walls in ruminant nutrition. - Journal of Nutrition 127: 810-813.

[27] Jung, G. A., Gross, C. F., Kocher, R. E., Burdette, L. A., Sharp, W. C. (1978): Warm season range grasses extend beef cattle forage. - Penn. Agric. Exp. Stn. Sci. Agric. 64: 211-219.

[28] Kiraz, A. B. (2011): Determination of relative feed value of some legume hays harvested at flowering stage. - Asian Journal of Animal Veterinary Advances 6(5): 525-530.

[29] Larbi, A., J. Lazier, Ochang, J., Addie, A. (1995): Dry matter production of thirteen tropical legumes in association with rhodes grass (Chloris gayana cv. Callide) on an acid soil in Etiopia. - Tropical Grasslands Volume 29: 88-91.

[30] Lemus, R. (2009): Seeding warm season perennial grasses. - Forage News, Mississippi State University Extension Service, March, 2009.

[31] Linn, J. G., Martin, N. P. (1999): Forage quality tests and interpretations. http://extension.umn.edu/distribution/livestocksystems/ID2637.html (accessed June 10, 2014).

[32] Nung, H. V., Binh, L. H. (2014): Forage productivity of guinea grass in different farming systems. - http://www.fao.org/ag/agp/agpc/doc/publicat/VIET95/V95_97.PDF (accessed April 15, 2014).

[33] Pinkerton, B. W., Cross, D. L. (1992): Forage quality. - http://www.clemson.edu/ psapublishing/ Pages/AGRO/forage16.pdf (accessed June 15, 2014). 
[34] Rohweder, D. A., Keuren, R. W. (1985): Permanent Pastures. - In: Heath, E., Barns, F., Metcalfe, S. (eds.) Forages. Iowa State University Press, Iowa, pp. 487-495.

[35] Schroeder, J. W. (1994): Forage nutrition for ruminants. - AS-1250. www.ag.ndsu.edu.tr.

[36] Sheaffer, C. C., Peterson, M. A., Mccalin, M., Volene, J. J., Cherney, J. H., Johnson, K. D., Woodward, W. T., Viands, D. R. (1995): Acid detergent fiber, neutral detergent fiber concentration and relative feed value. - North American Alfalfa Improvement Conference, Minneapolis.

[37] Skerman, P. J., Riveros, F. (1990): Tropical Grasses. - Plant Production and Protection Series 23. FAO, Rome.

[38] Sleugh, B., Moore, K. J., George, J. R., Brummer, E. C. (2000): Binary legume grass mixtures improve forage yield, quality, and seasonal distribution. - Agron. J. 92: 24-29. DOI: 10.2134/agronj2000.92124.

[39] Spandl, E., Hesterman, O. B. (1997): Forage quality and alfalfa characteristics in binary mixtures of alfalfa and Bromegrass or Timothy. - Crop Science 37: 1581-1585.

[40] Steel, R. G. D., Torrie, J. H. (1960): Principles and Procedures of Statistics with Special Reference to the Biological Sciences. - Mc Graw-Hill, London.

[41] Tessema, Z., Baars, R. M. T. (2006): Chemical composition dry matter production and yield dynamics of tropical grasses mixed with perennial forage legumes. - Tropical Grasslands Volume 40: 150-156.

[42] Uzun, F. (2010): Changes in hay yield and quality of bulbous barley at different phenological stages. - Turk. J. Agric. For. 34: 1-9. 